\title{
A conceptual approach to the biomonitoring of freshwater: the Ecological Ambience System
}

\author{
Michel LAFONT \\ CEMAGREF, UR Biologie des Ecosystèmes Aquatiques, 3bis Quai Chauveau, C.P. 220, F-69 336 Lyon Cedex 09, France \\ e-mail: michel.lafont@cemagref.fr
}

\begin{abstract}
The concept of ecological ambience (Ecological Ambience System, EASY) is based on the idea that biocenoses (BIO) are not only related to the input of organic and mineral substances (IN) but also to the way they are stored and processed by the ecosystem. Storage, assimilation and self-purification processes ("ecosystem defences": ED) are likely to vary among the different functional units (FUs) of the ecosystem. The functional units have been defined on the basis of a simple physical description of sites in an ecosystem, because the physical structure of these units is considered as being of prime importance in the ED processes. For example, mineral and organic substances may be preferentially stored in fine-sediment units, whereas the mineralization rate of organic matter is more likely to be highest in coarse permeable sediments. If the stream ecosystem is viewed as a mosaic, its overall ecological defences will depend upon: 1) the self-purification capacity of the different functional units; 2) their relative proportion within the ecosystem. The EASY concept is now used for ecological researches and also has several applications in the biomonitoring of running waters, illustrated by the study of the River Dore. Biological compartments, specific for each functional unit, are related to operational bio-indicators to build up a global harmonisation system for biomonitoring indices. Four main biological compartments were defined with their related bio-indicators: 1) general biological quality (IBGN biotic index), 2) biological sediment quality (IOBS oligochaete index), 3) biological water quality (diatom index IBD) and 4) biological fish quality (study of fish communities). The selected bio-indicators were adjusted to an ecological classification model (Typic concept). A weighting system of the general ecological quality at a site based on the percentage cover of fine sediments is proposed. This approach can be developed using several other compartments. Major difficulties and potential improvements are discussed.
\end{abstract}

Key words: Ecology, freshwater, biomonitoring, harmonization

\section{INTRODUCTION}

The restoration ecology of aquatic ecosytems is now one of the challenges of the future, as stated by Western (1992). Nevertheless, it is difficult to propose restoration rules, including limitations on polluted inputs, without focusing on the study of aquatic ecosystem functioning. The risk is that of establishing inefficient or dangerous management rules, because it is not really known how harmful substances are assimilated, stored or released in field conditions. In studies on the effects of polluting substances on aquatic life, biocenoses are commonly thought to be related to the nature and concentrations of organic and mineral inputs only by analogy with laboratory bioassays. In fact, these relations are actually observed in the case of grossly polluted conditions (Lafont 1989; Prygiel et al. 1999). For slight to moderate chemical loads, the importance of the selfpurification capacity of ecosystems becomes essential and is generally not studied. This is probably one of the possible explanations of several conflicting results between chemical and biological data (Prygiel et al. 1999). In addition, self-purification processes must be considered in the management of aquatic systems, particularly in the context of the EU Directive (UE 2000) which emphasises the conservation or restoration of good ecological quality.
The problem is that the study of how an aquatic ecosystem functions is a bewildering task, as it is extremely complex. Several general ecological concepts have already been propounded, like the Patch Dynamic Concept (Townsend 1989), the Habitat Templet (Townsend \& Hildrew 1994) or the Telescoping Ecosystem Model (Fischer et al. 1998a). But ecological concepts tend to be difficult to put in a concrete form for applied field studies. The problem is also that too simple or too general concepts like "ecosystem health" seem rather to be metaphors for communication purposes than scientific theories (Sutter II 1993). The same is true for concepts like "ecosystem or nature balance" (Western 1992). But what seems certain is the real need to develop operational concepts for applied researches.

Hence the recent proposal of an "Ecotoxicological Ambience Concept" (Lafont 1997). This concept was first proposed for assessing the field effects of harmful substances on living communities. Our researches now are focusing on the ecological effects of combined sewer overflows (CSOs) on urban streams (Lafont et al. 2000). In these studies, it is not easy to predict, eradicate and purify these particular inputs, and the characteristics of the receiving streams must be considered (Borchardt \& Statzner 1990). A consideration of the self-purification capacities of the streams proved to be essential, as consequently was the study of their func- 


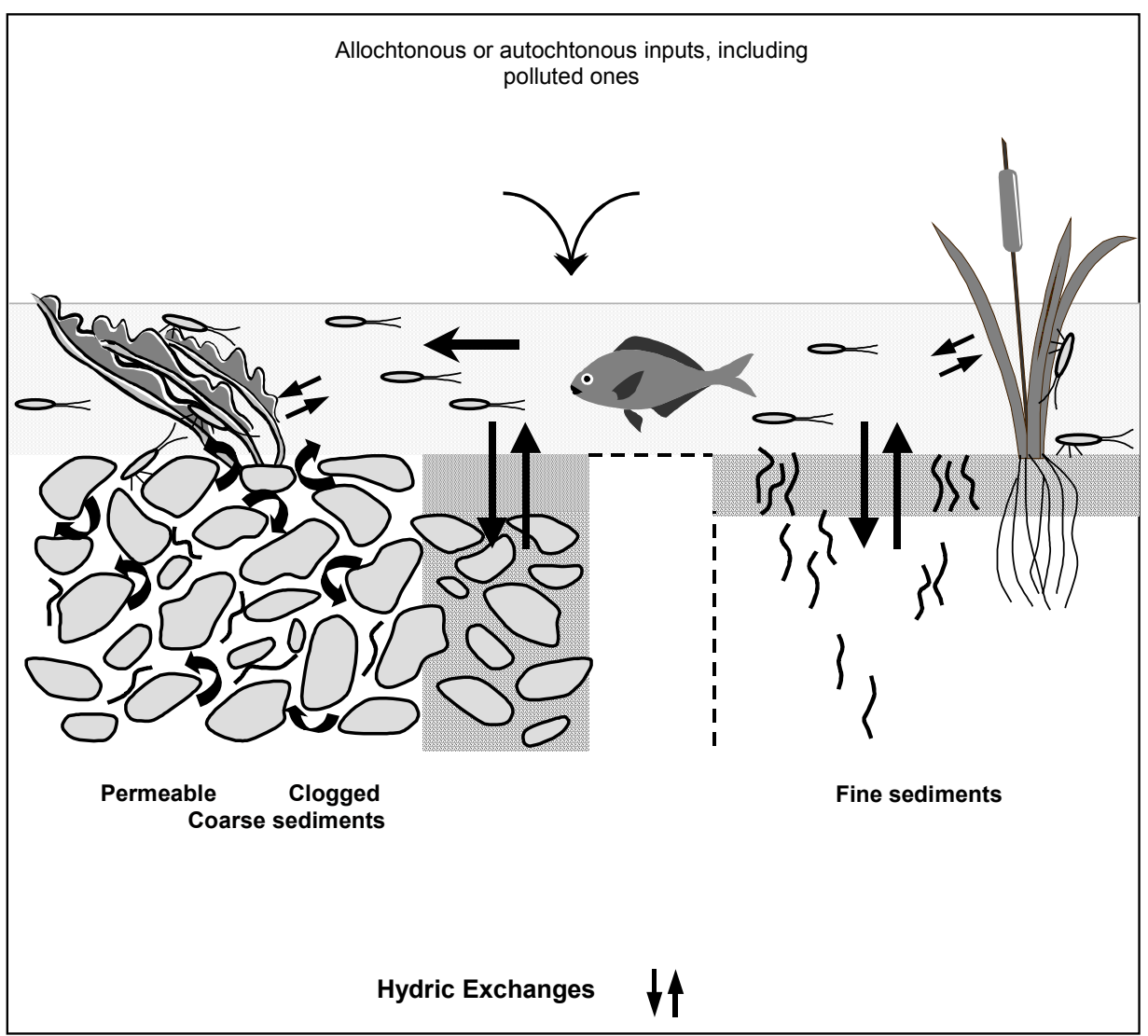

Fig. 1. Schematic view of the general physical structure of coarse and fine sediments.

tional dynamics. These last observations were the basis of the proposals of the EASY concept (Lafont 2000), which derives from the above-mentioned "Ecotoxicological Ambience Concept". We illustrate how this approach can already be developed using several existing bio-evaluation indices, discuss major difficulties and suggest potential improvements.

\section{THE EASY CONCEPT (ECOLOGICAL AMBIENCE SYSTEM)}

It is claimed that the biocenoses (BIO) of an ecosystem are related to the "ecological ambience" (EA) they find in this ecosystem. This ambience is itself related to the organic and mineral inputs (IN), and to all the processes of storage, self-purification and assimilation/degradation of these inputs by the ecosystem ("ecosystem defences", ED).

$$
\mathrm{BIO}=\mathrm{k}(\mathrm{EA}) \rightarrow \mathrm{BIO}=\mathrm{f}(\mathrm{IN})-\mathrm{g}(\mathrm{ED})
$$

The IN factor is characterised by the quantity, the fluxes, and the physico-chemical qualities of allochthonous and autochthonous inputs. The ED factor is characterised by all the processes involved in self-purification, including biological, chemical and physical factors. Obviously, the trophic foodweb structures and bioturbation are of great importance, as is the oxygen content. But physical factors, whether hydraulic, geo- morphological or hydrogeological, are equally important. It is self-evident that, for a given input of substances (quality and quantity), the dynamics of assimilation/degradation are not the same when there is dominance of porous sediments, with deep networks of interstices where water percolates through (coarse sediments), rather than fine sediments, with different layers and still overlying waters (Fig. 1). It has been known for a long time that sewage-filter beds (porous systems) are more efficient than fine deposits at mineralising organic matter. If the stream ecosystem is viewed as a mosaic, its overall "ecological defences" will depend upon: 1) the self-purification capacity of the units constituting the mosaic; 2) the relative proportion and spatial organisation of these units within the ecosystem. The study of functional units (FUs) originated from the recognised importance of the mosaic within the ecosystem (Lafont 2000).

\subsection{Functional unit (FU)}

To give the EASY concept a concrete form, it was therefore necessary to consider small-scale units at sites of the running water ecosystem studied. The size of each site is defined according to the French standard IBGN (AFNOR 1992): the length of a site is 10 times its width. At each site, several functional units (FUs) are defined on the basis of a rough physical classification of 


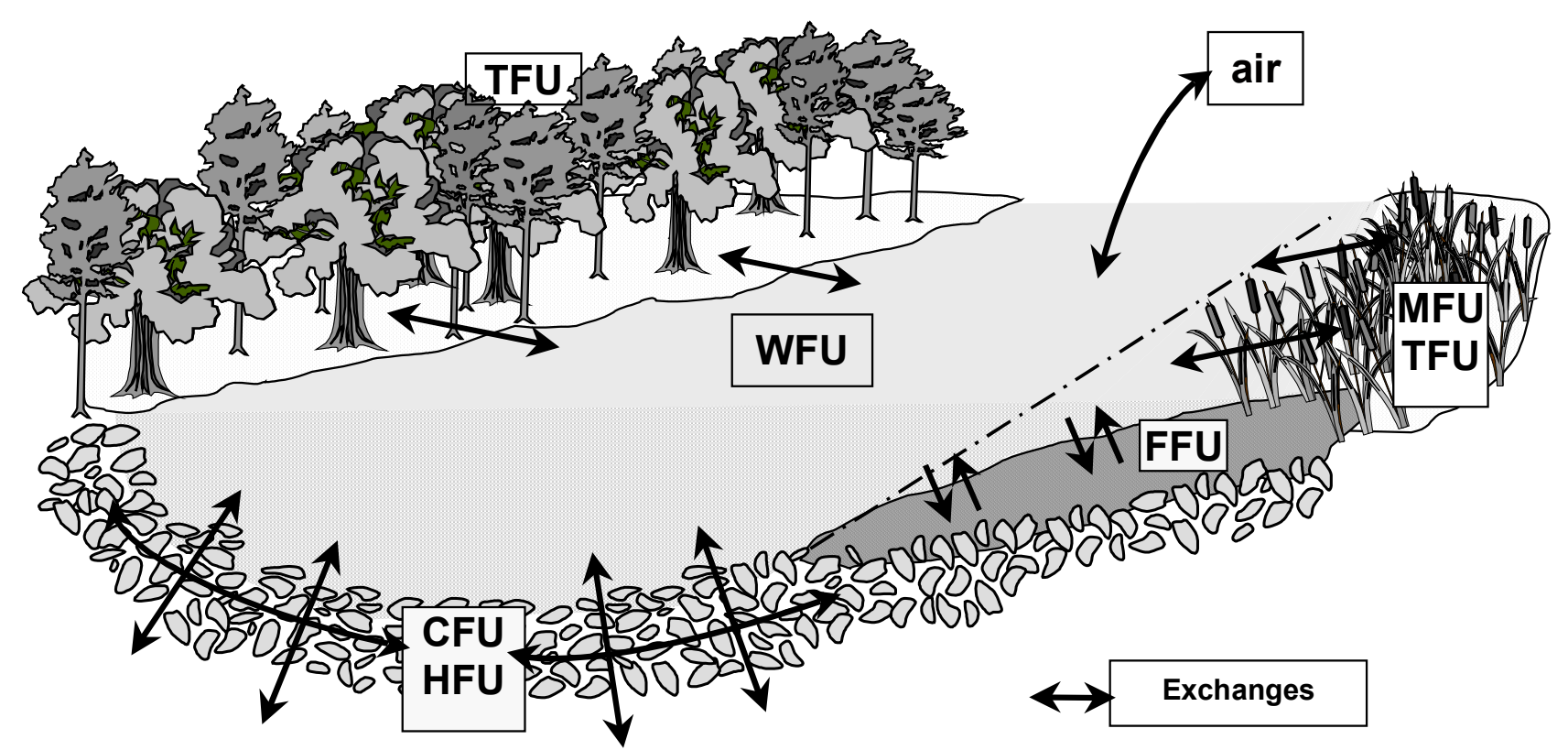

Fig. 2. Definition of functional units (FUs) at a site of a river; TFU: terrestrial FU; WFU: water FU; CFU: coarse sediment FU; HFU: hyporheic FU; FFU: fine sediment FU; MFU: macrophyte FU.

the habitats. Seven FUs were thus defined (Fig. 2): 1) terrestrial banks (TFU); 2) water (WFU); 3) coarse surface sediments (CFU); 4) fine surface sediments (FFU); 5) macrophytes, because they are a habitat for all other biocenoses (MFU); 6) flat habitats, where biofilms predominate (boulders, flagstones...; BFU); 7) hyporheic system (HFU). This classification was based on a hierarchical classification of stream habitats (Frissel et al. 1986): the functional units (FUs) roughly fit the "pool/riffle" system. In a given FU, the EASY concept becomes:

$$
\begin{gathered}
\mathrm{BIO}_{\mathrm{FUi}}=\mathrm{k}\left(\text { Ecological Ambience }_{\mathrm{FUi}}\right) \rightarrow \\
\rightarrow \mathrm{BIO}_{\mathrm{FUi}}=\mathrm{f}\left(\mathrm{IN}_{\mathrm{FUi}}\right)-\mathrm{g}\left(\mathrm{ED}_{\mathrm{FUi}}\right)
\end{gathered}
$$

This formula is the basis of the EASY concept development. The biocenoses of a whole site (BIO) are related to the relative importance of the different FUs at the site:

$$
\mathrm{BIO}=\% \mathrm{BIO}_{\mathrm{FUi}}+\% \mathrm{BIO}_{\mathrm{FUj}}+\% \mathrm{BIO}_{\mathrm{FUk}} \ldots
$$

As mentioned above, the EASY concept is now used in researches focusing on the assessment of ecological incidences of CSOs on urban streams. The concept also has several operational applications in the biomonitoring of running waters.

\section{APPLICATION OF THE EASY CONCEPT TO THE BIOMONITORING OF RUNNING WATERS}

A biomonitoring system was recently proposed by Lafont et al. (2001) and tested on the River Dore (Tab. 1). The system is intended both for the ecological assessment of rivers and the harmonisation of bio- monitoring indices. It takes three main elements into account:

a) a model of ecological quality classification (TYpology of Pollution Incidence Concept, TYPIC);

b) an overall view of a given aquatic site through four biological compartments, with their specifically connected operational biological indicators;

c) the adjustment of the biological indicators to the model for each of the four compartments.

The TYPIC concept was devised earlier, but the definition of biological (and ecological) compartments derives directly from the EASY concept. It was essential to first define the biological criteria considered as characteristic of each FU at a given site: these criteria are the "biological compartments" (Tab. 1). The GBQ (general biological quality) compartment is regarded as a rough characterisation of the biocenoses (BIO) of all the existing FUs at a given site. The SBQ, WBQ and FBQ compartments characterise the biocenoses of fine sediments and water FUs. The operational bio-indicators are afterwards adjusted to the TYPIC model (Lafont et al. 2001). To be operational, a bio-indicator must have been previously validated by chemical factors (Lafont \& Rosso 1995), and also standardised or in the process of being standardised, which is the case for IBGN, IBD and IOBS (Tab. 1).

\subsection{Weighting of the general ecological quality}

It has already been stated that the biocenoses of a whole site (BIO) are related to the relative importance of the different functional units (FUs) at this site. But the different FUs and consequently the different bio- 
Tab. 1. System of biomonitoring (from Lafont et al. 2001); biological and ecological compartments and the most recent connected operational bio-indicators; EASY concept: FU: functional units; BIO: biocenoses.

\begin{tabular}{|c|c|}
\hline $\begin{array}{l}\text { Operational concept } \\
\text { (definition of a range of ecosystem alterations) }\end{array}$ & $\begin{array}{l}\text { TYPIC model ("TYpology of Pollution Incidence Concept", Lafont 1989, } \\
\text { Lafont \& Rosso 1995): } 8 \text { ecological conditions: } \\
\text { S0, S1: High to very good ecological qualities (blue); } \\
\text { S2: good quality (green) but slight alterations; } \\
\text { S3: fair quality (yellow): significant alterations; } \\
\text { S4: poor quality (orange): high numbers of tolerant taxa; } \\
\text { S5: bad quality (red): tolerant taxa only found with low numbers; } \\
\text { S6 : extreme toxicity (black), invertebrates are absent; } \\
\text { S7: no living organisms at all (black): highest toxic conditions. }\end{array}$ \\
\hline $\begin{array}{l}\text { Biological compartments } \\
\text { (EASY concept) }\end{array}$ & $\begin{array}{l}\text { GBQ: General Biological Quality = BIO of all FUs at a given site } \\
\text { SBQ: Sediment Biological Quality = BIO of FFU (fine sediment) } \\
\text { WBQ: Water Biological Quality = BIO of WFU (water); gives also an idea } \\
\text { of BFU (flat substrata with the predominance of biofilms) } \\
\text { FBQ: Fish Biological Quality = BIO of WFU (water) }\end{array}$ \\
\hline Connected operational bioindicators & $\begin{array}{l}\text { GBQ: IBGN (AFNOR 1992) } \\
\text { SBQ: IOBS oligochaete index (AFNOR 2001); } \\
\text { WBQ: IBD (diatom index, AFNOR 2000) } \\
\text { FBQ: Fish indices, not still operational (Oberdorff \& Hugues 1992; Oberdorff } \\
\text { et al. 1999) }\end{array}$ \\
\hline Ecological compartments & $\begin{array}{l}\text { GEQ: General ecological quality (derives from the examination of the } 4 \\
\text { biological compartments) } \\
\text { GEQO: General ecological quality objectives (derives from the GEQ) }\end{array}$ \\
\hline
\end{tabular}

Tab. 2. Proposals for the weighting of the general ecological quality (GEQ) by the percentage cover of fine or sandy sediments (PCS); SBQ: sediment biological quality; TYPIC: Typology of Pollution Incidence Concept (see Tab. 1; S0-S1: high to very good ecological qualities; S2-S3-S4-S5: good to bad qualities; S6: highest toxic conditions).

PCS is less than $10 \%$ : the importance of the biological quality of sediments SBQ must be reduced and importance is given to other biological compartments to assess the GEQ:

- if SBQ has a better ecological quality than GEQ $\rightarrow$ one class of ecological quality (TYPIC) at least is added to the GEQ

- if SBQ has a poorer ecological quality than GEQ $\rightarrow$ one class of ecological quality (TYPIC) at least is subtracted from the GEQ

PCS is $10 \%-30 \%$ : no weighting

PCS is $30 \%$ to $60 \%$ : the importance of the biological quality of sediments SBQ must be magnified compared to other biological compartments:

- if SBQ has a better ecological quality than GEQ $\rightarrow$ one class of ecological quality (TYPIC) at least is subtracted from the GEQ

- if SBQ has a poorer ecological quality than GEQ $\rightarrow$ one class of ecological quality (TYPIC) at least is added to the GEQ

PCS is greater than $60 \%$ : the SBQ and WBQ (biological quality of water) only must be considered to assess the GEQ

logical compartments do not have the same quantitative importance in a given ecosystem. This is one of the failures of the present biomonitoring system.

To improve the system, it was proposed to weight the general ecological quality (GEQ) by the biological quality (SBQ) of the "fine sediments" FU (FFU) and by taking into account the percentage cover of this FU at a given site (Tab. 2). Fine sediments were chosen because they accumulate, store, or release nearly all the substances conveyed through an ecosystem, including harmful ones, and they represent a potential source of pollution (Prygiel et al. 1999).

At a given site, if the percentage cover of sediments (PCS) is small ( $<10 \%$, Tab. 2), and the SBQ character- 
Tab. 3. Example of general ecological quality (GEQ) weighted by the percentage cover of sediments PCS at 5 sites of the River Dore; SBQ: fine sediment biological quality.

\begin{tabular}{clcccc}
\hline Sites & PCS & GEQ & SBQ & Weight & Weighted GEQ \\
\hline 1 & $15 \%$ (Fine sediments, banks) & S3 & S4 & 0 & S3 \\
2 & $10 \%$ (Sandy sediments, banks) & S2 & S1 & +1 & S3 \\
3 & $10 \%$ (Sandy sediments, banks) & S3 & S4 & -1 & S2 (SBQ = alarm) \\
& & & & & \\
4 & $20 \%$ (Sandy sediments, banks) & S2 & S3 & 0 & S2 \\
5 & $50 \%$ (Fine sediments, reservoir) & S3 & S4 & +1 & S4 (SBQ = worrying) \\
\hline
\end{tabular}

Tab. 4. Proposals for a characterisation of different types of pollution effects by the harmonisation system; GBQ: biological general quality; SBQ: biological sediment quality; WBQ: biological water quality; FBQ: biological fish quality.

\begin{tabular}{|c|c|c|c|c|c|c|c|}
\hline S0-S1 & $\mathrm{S} 2$ & S3 & S4 & S5 & S6 & & \\
\hline $\begin{array}{c}\bullet \\
\bullet \\
\bullet \\
\bullet \\
(1)\end{array}$ & $\begin{array}{l}\bullet \\
\bullet \\
\bullet \\
\bullet \\
(2)\end{array}$ & $\begin{array}{l}\bullet \\
\bullet \\
\bullet \\
\bullet \\
\text { (3) }\end{array}$ & $\begin{array}{l}\bullet \\
\bullet \\
\bullet \\
\bullet \\
\dot{(4)}\end{array}$ & $\begin{array}{c}\bullet \\
\bullet \\
\bullet \\
\bullet \\
(5)\end{array}$ & $\begin{array}{l}\bullet \\
\bullet \\
\bullet \\
\bullet \\
\text { (6) }\end{array}$ & $\begin{array}{c}\text { GBQ } \\
\text { SBQ } \\
\text { WBQ } \\
\text { FBQ } \\
\text { GEQ }\end{array}$ & $\begin{array}{l}(1,2) \text { Very good or good general quality. } \\
(3) \text { Organic pollution. } \\
(4,5) \text { Bad or very bad quality (toxic } \\
\text { conditions); (6): highest toxic conditions. }\end{array}$ \\
\hline S0-S1 & $\mathrm{S} 2$ & S3 & S4 & S5 & S6 & & \\
\hline $\begin{array}{l}\bullet \\
\bullet\end{array}$ & & • & & & & $\begin{array}{l}\text { GBQ } \\
\text { SBQ } \\
\text { WBQ } \\
\text { FBQ }\end{array}$ & $\begin{array}{l}\text { Physical stress of natural (substrate } \\
\text { homogeneity for example) and/or human } \\
\text { origins; effects of acidification... }\end{array}$ \\
\hline S0-S1 & $\mathrm{S} 2$ & S3 & S4 & S5 & S6 & & \\
\hline$\bullet$ & & $\bullet$ & & & & $\begin{array}{l}\text { GBQ } \\
\text { SBQ } \\
\text { WBQ } \\
\text { FBQ }\end{array}$ & $\begin{array}{l}\text { Intermittent or non-point sources of slight to } \\
\text { moderate organic pollutions. }\end{array}$ \\
\hline S0-S1 & S2 & S3 & S4 & S5 & S6 & & \\
\hline$\bullet$ & & & • & & & $\begin{array}{l}\text { GBQ } \\
\text { SBQ } \\
\text { WBQ } \\
\text { FBQ }\end{array}$ & $\begin{array}{l}\text { Heavy contamination of sediments by toxic } \\
\text { substances, not still harmful for other } \\
\text { compartments; use a weighting factor for the } \\
\text { general ecological quality assessment (GEQ). }\end{array}$ \\
\hline
\end{tabular}

istic of a toxic condition, this means that poisonous substances are present, but that their accumulation is restricted to small areas of the site. The sediments are an alarm signal in such a situation. On the other hand, if toxic sediments cover a high percentage of the streambed at a given site, for example $50 \%$ (Tab. 2), the situation becomes very worrying as harmful substances are present and very abundant.

Examples of applications of the weighting factor are given for the River Dore (Tab. 3). There may also be cases when the biological quality of sediments is more "optimistic" than the other biological compartments (site 2), probably when slight to moderate non-point or intermittent organic pollutions are present (Lafont et al. 2001).

\subsection{Contribution to the ecological assessment of the incidence of specific pollutions}

It might be interesting to assess different types of pollution effects by considering the similarities and contradictions between the four biological compartments (Tab. 4). It is well known that physical stresses have an incidence on the general biological quality at a given site, by for example decreasing the diversity of habitats or clogging coarse sediments by silt. They may have no incidence on the biological qualities of fine sediments and water, except if harmful substances or polluted sludges are released, or if suspended matter is strongly increasing. Acidification also has a harmful effect on the general biological quality; this is a well- 
Tab. 5. Proposals of an extension of the biomonitoring system by the consideration of new compartments; GBQ: biological general quality; SBQ: biological fine sediment quality; WBQ: biological water quality; FBQ: biological fish quality; TBQ: trophic status; CBQ: biological quality of surface coarse sediments; HBQ: biological hyporheic quality; GEQ: General ecological quality; WGEQ: weighted general ecological quality; GEQO: general ecological quality objectives; CQW: chemical quality of waters; CQS: chemical quality of sediments; PHQ: physical quality; Others...: terrestrial environment, bio-markers etc.

\begin{tabular}{|c|c|c|c|c|c|c|c|}
\hline \multicolumn{2}{|c|}{$\operatorname{Site}(\mathrm{s}): \ldots \ldots$} & \multicolumn{2}{|c|}{ Date(s):...... } & \multicolumn{4}{|c|}{ (and other informations, etc.)..... } \\
\hline S0-S1 & S2 & S3 & S4 & S5 & S6 & & \\
\hline & & & & & & GBQ & \multirow[t]{14}{*}{ Comments:..... } \\
\hline & & & & & & SBQ & \\
\hline & & & & & & WBQ & \\
\hline & & & & & & FBQ & \\
\hline & & & & & & TBQ & \\
\hline & & & & & & CBQ & \\
\hline & & & & & & HBQ & \\
\hline & & & & & & GEQ & \\
\hline & & & & & & WGEQ & \\
\hline & & & & & & GEQO & \\
\hline & & & & & & CQW & \\
\hline & & & & & & CQS & \\
\hline & & & & & & PHQ & \\
\hline & & & & & & Others... & \\
\hline dit & & & & & & & \\
\hline
\end{tabular}

known phenomenon in the French Vosges Mountains (Guérold et al. 1995) but not observed in the River Dore. Intermittent or non-point sources of slight to moderate organic pollution affects fish and diatoms rather than the other biological compartments. Bioavailable toxic substances stored in the "fine sediments" functional unit may provisionally have an incidence only on the SBQ (sediment biological quality), especially when the pollutants have not yet been released. In such a situation a weighting factor must be used to assess the general ecological quality, as the release of pollutants may affect all the biological compartments. All the situations of conflicting results (Tab. 4) were observed in the River Dore (Lafont et al. 2001).

\subsection{Prospects for future developments}

The biomonitoring system must be extended by taking other biological compartments into consideration (Tab. 5), especially the biocenoses of the FUs "hyporheic system" (HFU) and "macrophytes"(MFU). The macrophyte communities occupy a particular place as they constitute a substrate for other biocenoses, including fish, and are also a biocenosis of primary producers. Macrophytes are of great importance in assessing the ED factor ("ecosystem defences") of the EASY concept, and the macrophyte index of Haury et al. (1996) is now in the process of being standardized. There is also the idea of adding the chemical qualities of the water and sediments and of considering a physical quality compartment. The biomonitoring scheme (Tab. 5) is intended for future operational uses, with standardized cards from easily accessible software.

\section{DISCUSSION AND CONCLUSION}

The main difficulty in the development of a study like this one is to reconcile a theoretical approach with an operational approach. It is beyond the scope of this paper to discuss functional ecological concepts. It had the more modest aim of putting forward an alternative operational concept, as simple as possible, but establishing a link between operational tasks and theoretical models. It is for example possible to include the EASY concept in other conceptual approaches, like the Web approach (Verdonschot \& Nijboer 2000), the Telescoping Ecosystem Model (Fischer et al. 1998a), the PDC and Habitat Templet theories (Townsend 1989, Townsend \& Hildrew 1994). It was also conceived as a guideline for developing functional researches, including those focusing on the ecological effects of combined sewer-overflows on urban streams (Lafont et al. 2000).

However, the EASY concept and its operational applications are open to many criticisms.

1) All the operational applications (biomonitoring system) were tested only on the River Dore, as this river was a workshop-site. There is now a plan to test all the present and prospective applications on other rivers, including urban streams.

2) The terminology used is a matter for discussion, as a standard terminology has not yet been proposed in France or at an EU level. As yet, no solutions to this problem have been put forward.

3) The statistical background for the validation of the operational applications is lacking, but the opera- 
tional bio-indicators connected to the compartments (IBGN, IOBS, IBD, Tab. 1) have already been statistically validated by physico-chemical data and standardized or in the process of being standardized (AFNOR 1992; AFNOR 2000; 2001). In fact, the harmonization system (Tabs 4 and 5) settles a matrix with data transformed into quality classes. This matrix may be treated by multi-variate statistics, considering quality classes or fuzzy-coding of data (Chevenet et al. 1994).

4) The rough classification of the FUs (functional units) is not an original concept. The idea of considering the habitat mosaic at a given site for biomonitoring studies is relatively old (Verneaux 1982). But the use of less rough field classifications leads in my opinion to errors, as a relevant field habitat classification needs precise physical, chemical and biological measurements, which are not always possible in the field. Several intermediate conditions exist, like that of coarse substrata clogged by fine mineral deposits and/or polluted sludges. This last feature may be assessed for example by laboratory examination of the percentages of Tubificidae (Oligochaeta), which become abundant when coarse sediments are clogged by organic or toxic sludges (Brinkhurst 1965). The clogging of coarse substrata is considered as a "functional trait" requiring validation by chemical and physical laboratory analyses (Lafont 2000; Lafont et al. 2000). It is also important to consider both surface and hyporheic sediments in a biomonitoring system, as already suggested by Hynes (1983). Consideration of the hyporheic compartment is essential for an understanding of the ecology of running water (Danielopol 1989; Ward \& Palmer 1994; Malard et al. 1999), and of prime importance when assessing the vulnerability of subterranean waters to surface water pollution (Lafont et al. 1992, 1996).

5) One of the main problems involves the terrestrial functional unit (TFU), the importance of which has long been recognised in the study of aquatic ecosystem ecology (Pautou \& Décamps 1985). The study of this FU necessitates collaboration with terrestrial ecologists before operational applications can be contemplated.

6) The main danger of the EASY concept lies in the misinterpretation of the ED factor (ecosystem defences). The risk is that of viewing the ecosystem as a sewage-treatment plant. The ED factor is important in assessing the effects of pollution and for establishing rules of management, including input eradication, aimed at good ecological quality conservation or restoration. But the ED factor was not conceived to give the green light to pollution in those ecosystems with high ED capacities.

The EASY concept places trophic factors at the centre of ecology. Without nutrients, no life is possible.
If they are present but not in a bio-available form ("bioavailability" of nutrients), life is still not possible. If they are bio-available but not easy to use, for example for physical reasons (too high a current velocity, storage of nutrients in habitats which are not easily accessible, etc.), life remains impossible ("accessibility" of nutrients). The ED factor is viewed as a result of bio-availability and accessibility of nutrients (Lafont 2000). This means that the physico-chemical quality of water and sediments, hydrological, hydrogeological and geomorphological factors, assimilation processes etc., are just some of the ecological factors contributing to bio-availability and accessibility. It is surprising to find that even in the very harsh environment of a glacial river (very low temperatures and organic matter loads), oligochaetes are present and sometimes abundant at sites where upwellings of subterranean waters to surface water are significant (Malard et al. 2001, in press). There is still insufficient information available about trophic foodwebs, assimilation processes and rates, etc. The EASY concept was devised for the precise purpose of stimulating this kind of research, and its operational applications are planned to be used in running-water as well as still water ecosystems.

The assumption of using a weighting factor might eventually be extended to other functional units, provided a relevant operational FU-specific bio-indicator exists. For example, the HFU (hyporheic FU) has important related bio-indicators, like oligochaete or microcrustacean assemblages (Lafont et al. 1996), but these indicators are still in the process of being validated by field studies. Another problem is that the percentage cover of a site by the different FUs does not give an idea of their spatial structure at this site. This spatial configuration may be of a great importance in the dynamics of nutrient assimilation (Fischer et al. 1998b), and by extension in the characterisation of the "ecosystem defences" factor. This is another problem that will have to be taken into consideration in our future researches and their operational applications.

\section{ACKNOWLEDGMENTS}

The author is very grateful to Dr Oscar Ravera for his help in editing the manuscript, and to Dr Florian Malard (UMR CNRS 5023, Lyon) for his valuable criticisms, which improved the manuscript. His thanks also go to Christine Feray (Cemagref Lyon) for elaborating the figures.

\section{REFERENCES}

AFNOR. 1992. Essai des eaux: détermination de l'indice biologique global normalisé (IBGN). Norme NF T 90-350. AFNOR. 2000. Détermination de l'Indice Biologique Diatomées (IBD). Norme NF T 90-354.

AFNOR. 2001. Détermination de l'indice oligochètes de bioindication des sédiments (IOBS). Norme NF T 90-390.

Borchardt, D. \& B. Statzner. 1990. Ecological impact of urban stormwater runoff studied in experimental flumes: popu- 
lation loss by drift and availability of refugial space. Aquat. Sci., 52: 299-314.

Brinkhurst, R.O. 1965. Observations on the recovery of a British river from gross organic pollution. Hydrobiologia, 25: 9-51.

Chevenet, F., S. Dolédec \& D. Chessel. 1994. A fuzzy coding approach for the analysis of long-term ecological data. Freshwat. Biol., 31: 295-309.

Danielopol, D.L. 1989. Groundwater fauna associated with riverine aquifers. J. N. Am. Benthol. Soc., 8: 18-35.

Fisher, S.G., N.B. Grimm, E. Martí, R.M. Holmes \& J.B. Jones. 1998a. Material spiraling in stream corridors: a telescoping ecosystem model. Ecosystems, 1: 19-34.

Fisher, S.G., N.B. Grimm, E. Martí, \& R. Gómez. 1998b. Hierarchy, spatial configuration, and nutrient cycling in a desert stream. Aus. J. Ecol., 23: 41-52.

Frissell, C.A., W.J. Liss, C.E. Warren \& M.D. Hurley. 1986. A hierarchical framework for stream habitat classification: viewing streams in a watershed context. Environ. Management, 10: 199-214.

Guérold, F., D. Vein, G. Jacquemin \& J.C. Pihan. 1995. The macroinvertebrate communities of streams draining a small granitic catchment exposed to acidic precipitations (Vosges Mountains, northeastern France). Hydrobiologia, 300/301: 141-148.

Haury, J., M.C. Peltre, S. Muller, M. Trémolières, J. Barbe, A. Dutartre \& M. Guerlesquin. 1996. Des indices macrophytiques pour estimer la qualité des cours d'eau français: premières propositions. Ecologie, 27: 233-244.

Hynes, H.B.N. 1983. Groundwater and stream ecology. Hydrobiologia, 100: 93-99.

Lafont, M. 1989. Contribution à la gestion des eaux continentales: utilisation des Oligochètes comme descripteurs de l'état biologique et du degré de pollution des eaux et des sédiments. Thèse de Doctorat d'Etat ès Sciences, UCBL Lyon 1: $411 \mathrm{pp}$.

Lafont, M. 1997. Rapport d'activité du programme de recherche "Altérations physico-chimiques et biologiques des écosystèmes aquatiques». Cemagref, GMA: 40 pp.

Lafont, M. 2000. Proposition des bases conceptuelles d'une typologie fonctionnelle des milieux aquatiques continentaux: le Concept d'Ambiance Ecologique des Milieux aquatiques continentaux. Cemagref, GMA: $28 \mathrm{pp}$.

Lafont, M. \& A. Rosso. 1995. Contribution from CEMAGREF on the use of macrobenthos. In: The harmonised monitoring and classification of ecological quality of surface waters. Report No CO 4030, WRc, European Commission, DG XI: 207-226.

Lafont, M., A. Durbec \& C. Ille. 1992. Oligochaete worms as biological describers of the interaction between surface and groundwaters: a first synthesis. Regulated Rivers, 7 : $65-73$.

Lafont, M., J.C. Camus \& A. Rosso. 1996. Superficial and hyporheic Oligochaete communities as describers of pollution and water exchanges in the River Moselle system (France). Hydrobiologia, 334: 147-155.

Lafont, M., S. Bernoud, J.C. Camus, Ph. Namour, P. Breil \& P. Le Pimpec. 2000. Etat écologique d'un ruisseau périurbain soumis à des rejets de temps de pluie; premiers résultats et perspectives. Acta 2ème Symp. Internat.
Québec-Paris, La réhabilitation et l'aménagement des cours d'eau en milieu urbain. 18-20 octobre 2000, Paris : 11-22.

Lafont, M., J.C. Camus, A. Fournier \& E. Sourp. 2001. A practical concept for the ecological assessment of aquatic ecosystems: application on the river Dore in France. Aquat. Ecol., 35: 195-205.

Malard, F., K. Tockner \& J.V. Ward. 1999. Shifting dominance of subcatchment water sources and flow paths in a galcial floodplain, Val Roseg, Switzerland. Arct. Antarct. Alp. Res., 31: 135-150.

Malard, F., M. Lafont, P. Burgherr \& J.V. Ward. (2001). Longitudinal patterns of hyporheic versus benthic oligochaetes in a glacial river. Arct. Antarct. Alp. Res., 33(4): (in press).

Oberdorff, T. \& R.M. Hughes. 1992. Modification of an Index of Biotic Integrity based on fish assemblages to characterize rivers of the Seine Basin, France. Hydrobiologia, 228: 117-130.

Oberdorff, T., D. Pont, B. Hugueny, P. Boët, J.P. Porcher \& D. Chessel. 1999. Probabilistic model characterizing riverine fish communities of french rivers: a framework for the adaptation of a fish based index. $7^{\text {th }}$ Intern. Symp. on the Ecology of Fluvial Fishes (ISEFF), Penczak, Tadeusz, 10-13 mai 1999.

Pautou, G. \& H. Décamps. 1985. Ecological interactions between the alluvial forests and hydrology of the Upper Rhône. Arch. Hydrobiol., 104 : 13-37.

Prygiel, J., A. Rosso-Darmet, M. Lafont, C. Lesniak, A. Durbec \& B. Ouddane. 1999. Use of oligochaete communities for assessment of ecotoxicological risk in fine sediment of rivers and canals of the Artois-Picardie water basin (France). Hydrobiologia, 410: 25-37.

Sutter II, G.W. 1993. A critique of ecosystem health concepts and indexes. Environ. Toxicol. Chem., 12: 1533-1539.

Townsend, C.R. 1989. The patch dynamic concept of stream community ecology. J. Amer. Benthol. Soc., $8: 36-50$.

Townsend, C.R. \& A. Hildrew. 1994. Species traits in relation to a habitat templet for river systems. Freshwat. Biol., 31 : 265-275.

UE. 2000. Directive $2000 C E d u$ Parlement Européen et du Conseil établissant un cadre pour une politique communautaire dans le domaine de l'eau. Bruxelles, le 18 juillet 2000

Verdonschot, P.F. \& R.C. Nijboer. 2000. Typology of macrofaunal assemblages applied to water and nature management: a Dutch approach. In: Wright JF, D.W. Sutcliffe \& M.T. Furse (Eds.), Assessing the biological quality of fresh waters, RIVPACS and other techniques. Proc. Int. Workshop, Oxford, 16-18 September 1997. Freshwater Biological Association, UK: 241-262.

Verneaux, J. 1982. Une nouvelle méthode pratique d'évaluation de la qualité des eaux courantes. Un indice biologique de qualité générale (I.B.G.). Ann. Sci. Univ. F.C. Besançon, 3: 11-21.

Ward, J.V. \& M.A. Palmer. 1994. Distribution patterns of interstitial freshwater meiofauna over a range of spatial scales, with emphasis on alluvial river-aquifer systems. Hydrobiologia, 287: 147-156.

Western, D. 1992. The biodiversity crisis: a challenge for biology. Oikos, 63: 29-38. 